\title{
Continental and marine surficial water - groundwater interactions: the case of the southern coastland of Venice (Italy)
}

\author{
Luigi Tosi ${ }^{1}$, Cristina Da Lio ${ }^{1}$, Pietro Teatini ${ }^{1,2}$, Antonio Menghini ${ }^{3}$, and Andrea Viezzoli ${ }^{3}$ \\ ${ }^{1}$ Institute of Marine Sciences - National Research Council, Venezia, Italy \\ ${ }^{2}$ Department of Civil, Environmental and Architectural Engineering, University of Padova, Padova, Italy \\ ${ }^{3}$ Aarhus Geophysics Aps, Aarhus, Denmark \\ Correspondence: Luigi Tosi (luigi.tosi@ismar.cnr.it)
}

Received: 30 December 2017 - Revised: 1 March 2018 - Accepted: 7 March 2018 - Published: 5 June 2018

\begin{abstract}
Understanding the continental-marine surficial water-groundwater exchanges in transitional coastal environments is really challenging at large scale. It requires an image of the saltwater-freshwater relationship which is difficult to be obtained especially in wetlands, lagoons, and marine areas. This study is focused on the coastland of the southern Venice lagoon - northern Po river delta (Italy), a precarious environment subject to both natural changes and anthropogenic pressures. Here, saltwater severely affects farmlands and aquifers. We used an airborne electromagnetics (AEM) survey with the goal of characterizing the continental and marine surficial water-groundwater interactions in such coastal region. The AEM survey allowed depicting a clear image of the fresh water-saltwater occurrence in shallow aquifers along mainland-lagoon - littoral-sea profiles, up to $20 \mathrm{~km}$ long. The results reveal that continental groundwater is located in the lagoon subsoil below a $10-20 \mathrm{~m}$ thick saline aquifer and extends down to $70 \mathrm{~m}$ depth. The whole low-lying farmland located south of the lagoon margin is seriously affected by saltwater contamination, which occurs from a few to about $50 \mathrm{~m}$ depth. The integrated analysis of AEM, seismic and borehole data shows that buried morpho-geological structures, such as paleo-channels and over-consolidated clay units control the saline contamination from the lagoon and the sea into the coastal aquifer system.
\end{abstract}

\section{Introduction}

Transitional coastal environments have drawn much attention in the last decades because of the high ecological relevance of deltas, estuaries, lagoons, and wetlands with an increasing concern on their vulnerability, especially in view of the expected global changes.

The coexistence of agricultural, urban, and industrial areas with salt- and fresh-water wetlands makes the surface water-groundwater exchanges be impacted by both natural processes and human activities. Whilst the exchange of water among rivers, wetlands, lagoons and sea is fairly well understood at the local scale, the interactions between these waters and the on-shore and off-shore aquifers are often hard to be understood in such complex coastal environments. Therefore, investigating continental and marine surficial water- groundwater interaction, i.e. salt-freshwater exchange, in a unique, consistent, and homogeneous framework is still a challenge. Borehole electrical conductivity measurements, vertical electric soundings, electrical resistivity tomography, and time-domain electromagnetic investigations are usually performed to characterize the saline interface and its evolution in coastlands. Direct measurements such as seepage meters, benthic chambers, and surface water enrichments in natural isotopic tracers are often done to assess submarine groundwater discharge (SGD) in wetlands, lagoons and offshore. Nevertheless, a clear and comprehensive image of the mainland-lagoon - sea hydrogeology in a continuous framework is far from being achieved because inland and offshore surveys are generally carried out separately and by different methodologies. In addition, in-depth and extent investi- 


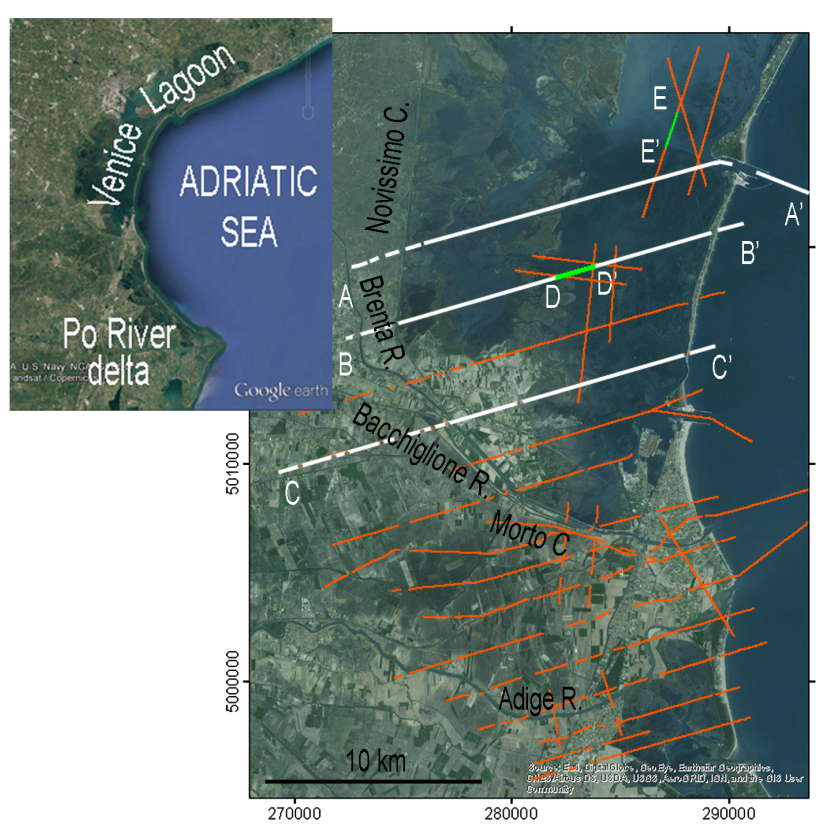

Figure 1. Satellite images of the southern Venice Lagoon - northern Po River Delta coastland. Red and white lines show the AEM acquisition tracks.

gations in lagoon shallows, marshes, rivers and reclamation canals are precluded or at least hardly and locally done.

The Venice coastland (Italy) is an example of heterogeneous transitional coastal zone (Fig. 1), which includes lowlaying farmland, lagoon, estuary, delta and littoral environments where water flows are often anthropogenically driven, especially in the low-lying sectors (e.g., Da Lio et al., 2015).

Over the last two decades, recurrent summer droughts and marine water encroachment along the river mouths severely affected the southern Venice coastland, especially the lowlying farmland, with salinization of soils and groundwater. Thus, a number of investigations have been carried out in order to understand the causes and the mechanisms concurring to the aquifer and soil salinization. Although most of the above mentioned methods have been already used (e.g., Carbognin and Tosi, 2003; Mayer et al., 2006; de Franco et al., 2009; Rapaglia, 2005; Tosi et al., 2011) a clear and comprehensive image of surficial water-groundwater interaction in a mainland-lagoon - sea unique, consistent and homogeneous framework, is still far from being achieved.

The aim of this work is to provide a step forward in the delineation of the continental and marine surface watergroundwater interactions and the mechanisms controlling the saltwater intrusion in the southern coastland of Venice. This has been achieved using an airborne electromagnetics (AEM) survey (Viezzoli et al., 2010), consisting of electrical resistivity sections up to $20 \mathrm{~km}$ long, acquired from the mainland to the sea, crossing lagoon, estuarine and delta environments. The AEM allows overcoming many intrinsic constrains typ- ical of the ground-based surveys, among all, the "simultaneity" of data acquisition. This method has been successfully tested in the Venice lagoon at local scale (Viezzoli et al., 2010; Teatini et al., 2011) and in this work we explored its potentiality for large scale analysis.

\section{Method}

About $200 \mathrm{~km}$-long AEM resistivity sections were acquired by the SkyTEM system in 2013 over the Venice coastland. This instrumentation was chosen as its dual moment provides a bandwidth (i.e. a penetration range) suitable for applications where near-surface and deep information is important to refine the hydrogeologic model (Viezzoli et al., 2010; Teatini et al., 2011). The AEM survey was acquired along NorthSouth and West-East profiles, crossing the farmland and watercourses in a continuous and like-simultaneous acquisition (Fig. 1). Data have been processed to eliminate artefacts and assign noise levels at late times, stacked to increase signal to noise ratio while preserving lateral resolution, and inverted using the Spatially Constrained Inversion (SCI) technique (Viezzoli et al., 2010). The accuracy of the resistivity model obtained from AEM data depends on the contrasts and the resistivity range. In highly conductive environment like lagoons and sea it is in the order of \pm few tens of $\%$. The interpretation of the AEM outcome has been supported by a number of groundwater and surficial water electrical conductivity measurements carried out simultaneously to the airborne survey (Da Lio et al., 2015) and available chemical analysis, subsoil data, and hydro-stratigraphic information (e.g., Carbognin and Tosi, 2003; Tosi et al., 2007; de Franco et al., 2009; Rizzetto et al., 2003; Tosi et al., 2009; Zecchin et al., 2011; Da Lio et al., 2013). Specifically, in this work, we assumed electrical resistivity $<5$ and $>10 \Omega \mathrm{m}$, as the upper value for saltwater and the lower value for freshwater, respectively.

\section{Results}

\subsection{Multi-layer vertical resistivity sections}

Three vertical resistivity sections have been selected from the whole AEM dataset to illustrate the onshore-offshore relationships between surface water and groundwater.

In most of the examined lagoon area, the salt water infiltrates into the subsoil down to $10-20 \mathrm{~m}$ depth, delineating an irregular freshwater-saltwater transition zone (Fig. 2). In the north-western sector, the saltwater intrusion is restricted to the lagoon margin or the surroundings of the Brenta and Bacchiglione rivers, while in the south-western sector the lagoon water contaminates a large part of the farmland. The presence of fresh waters in the lagoon basin has been identified beneath the shallow saline aquifer (Fig. 2). This freshwater flows from the mainland and laterally extends underneath the littoral to the near shore. Although the AEM data 
(a)

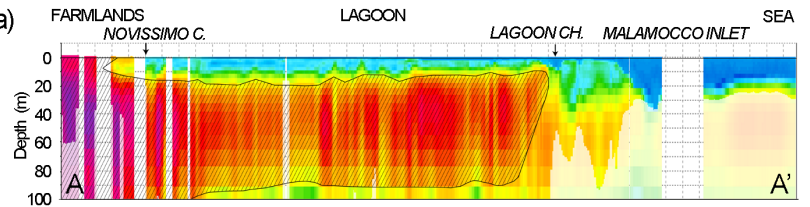

(b)

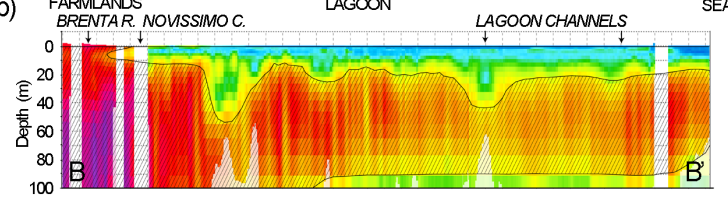

(c)

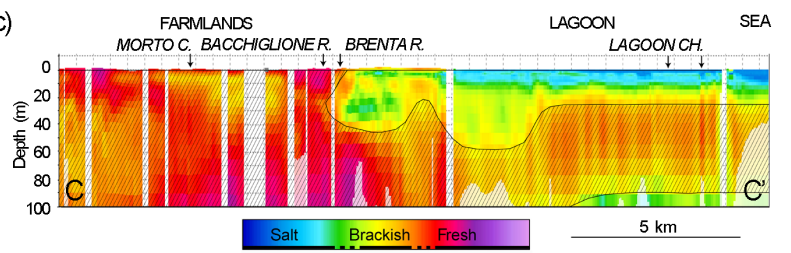

Figure 2. Multi-layer vertical resistivity sections obtained from the AEM survey (see section position in Fig. 1). The freshwaters are highlighted by a black oblique hatching.

quality rapidly decays with the increase of the lagoon and sea bathymetry, it is reasonably to suppose that continental groundwaters flow up to a few $\mathrm{km}$ offshore. In the lagoon sector, groundwater is salty again below $70-80 \mathrm{~m}$ depth, probably because of its fossil marine origin, while in the mainland freshwater aquifers occur (Fig. 2). Notice that in the lagoon sector, the AEM survey did not produce reliable data for a rigorous interpretation deeper than $100 \mathrm{~m}$.

\subsection{Model of the fresh water-saltwater interaction}

The pseudo-3-D electrical resistivity dataset provided by AEM is used to map the presence of saltwater and freshwater at different depths. Electrical resistivity data were interpolated on a $1 \mathrm{~km}$ regular grid by the Kriging method and the results classified as freshwater and saltwater for values $<5$ and $>10 \Omega \mathrm{m}$, respectively. The values between these limits are used to map the brackish transitional zone.

Figure 3 shows the conceptualization of the freshwatersaltwater relationships at four different depths. The first layer (0-1 m depth interval, Fig. 3a) highlights the marine-lagoon and the land areas by blue and red color, respectively, with the exception of some low-lying sectors in the southernmost zone where saltwater contaminates also agricultural soils. Freshwater below the Venice lagoon is unevenly detected between 10 and $20 \mathrm{~m}$ depth (Fig. 3b) and more generally occurred in the $60-70 \mathrm{~m}$ depth range (Fig. 3c). Southward of the lagoon margin, saltwater intrudes from the lagoon and the sea and extends to the whole mainland, including the northern Po River delta. Saltwater is encountered at depth larger than about $90-100 \mathrm{~m}$ in the aquifers below the lagoon while freshwaters are detected in the mainland sectors (Fig. 3d).
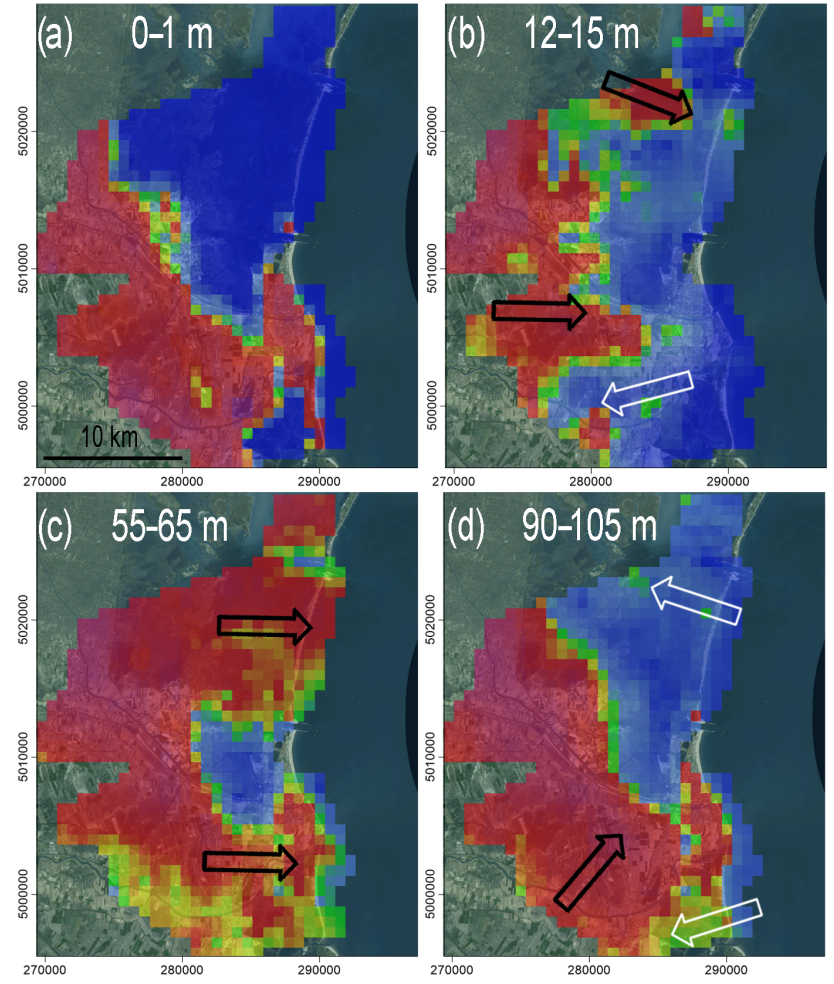

Figure 3. Conceptualization of the freshwater-saltwater relationship at different depths, obtained by integrating the results of the AEM survey with previous available information: (a) $0-1 \mathrm{~m}$, (b) 12-15 m, (c) 55-63 m, (d) 91-108 m. Fresh-, brackish- and saltwaters are represented by red, green/yellow and blue colors, respectively. White and black arrows delineate the advancement of the saltwater intrusion and freshwater flow, respectively.

\section{Discussion}

AEM provides a continuous image of the freshwater and saltwater distribution in the transitional coastal aquifers of the southern Venice lagoon and northern Po River Delta. Moreover, the integrated use of additional data, such as very high resolution seismic (VHRS) profiles together with geomorphological and sedimentological analyses, has allowed a clearer understanding of the mechanisms driving surface water and groundwater exchanges.

The analysis highlights that the high conductivity shallow deposits correspond to the Holocene units (Fig. 4), which are characterized by marine and lagoon-back barrier sediments, more permeable and less compacted than the deeper Pleistocene alluvial ones (e.g., Tosi et al., 2007 and references therein). The setting of the saltwater-freshwater transitional zone is very complex and likely related to the location of an aquitard partially confining the Holocene deposits, well known by Venetians as caranto. It consists in an overconsolidated stiff layer forming the uppermost part of the Pleistocene units (e.g., Bonardi et al., 2006; Tosi et al., 2007). 

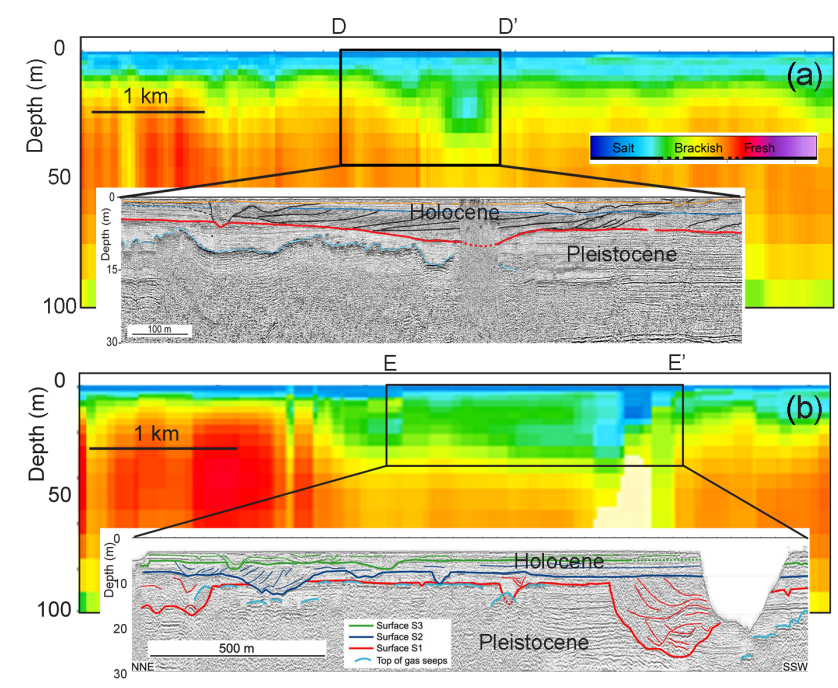

Figure 4. Vertical resistivity and seismic sections along the alignments D-D' (a) and E-E' (b) sketched in Fig. 1. The red line represents the Pleistocene-Holocene boundary.

Localized seepages of saltwater from the lagoon bottom at larger depths involving the Pleistocene deposits (Fig. 4) can be observed. Their location corresponds with the lagoon channels where the caranto clay layer misses. Other deeper saltwater infiltrations are related to the presence of buried paleo-channels, which are generally filled with coarse and more permeable sediments than those forming the lagoon bottom.

Similarly to the lagoon basin, also in the inland the morphology and subsoil architecture play an important role in determining the relationship between fresh and salt groundwater (Fig. 3). In the littoral sector, generally characterized by a ground elevation a few meter above the mean sea level, rainfalls favour the formation of rather continuous fresh groundwater lens, about $10 \mathrm{~m}$ thick and even more, in the sandy subsoil. Conversely, in the areas lying below the mean sea level (up to $4 \mathrm{~m}$ ) managed by hydraulic reclamation, saltwater contamination affects the farmland from the subsoil down to 50$60 \mathrm{~m}$ depth (Fig. 3). Moreover, the presence of sandy buried paleo-channel systems crossing the farmland, with a main direction from inland to the lagoon boundary, acts as preferential pathways for groundwater flow and solute transport. These structures generally increase the saltwater flow from the lagoon into the low-lying sectors, even though they allow a short-term storage of rainwater in the very shallow subsoil. Conversely, sandy paleo-ridge systems are capable to contain groundwater with lower salinity than that occurring in the paleo-channels, at least in the shallow part. For both paleo-channels and paleo-coastal ridges, the water quality is significantly improved by local rainfalls that rapidly supply freshwater.

\section{Conclusions}

We have explored the capability of the AEM technique to investigate the continental and marine surficial watergroundwater interactions in a large portion of the coastland encompassing the southern Venice lagoon and the northern Po river delta. The AEM has allowed to overcome the logistical problems typical of the ground-based measurements in coastal transitional environments crossed by rivers, canals and lagoons. AEM has provided a continuous and almost simultaneous image of the relative position of saltwater and freshwater, suggesting the main mechanisms governing the exchange between surface water and groundwater. Significant information on these water interactions has been obtained at "regional" scale and with a good detail even in some local situations. The main results are summarized as follows.

The infiltration of the lagoon and marine waters is less deep than it was supposed in the past.

Fresh and brackish waters have been identified underneath the lagoon basin from only $15-20 \mathrm{~m}$ depth, locally even less, and down to about 70-80 m. Below this depth, a saline aquifer probably of fossil origin is detected in the lagoon sector.

Fresh and brackish aquifers extend beyond the littoral to the nearshore and could give rise to local SGD.

The saltwater-fresh water transition zone is very irregularly-shaped and mainly depends on the morphologic setting and the subsoil architecture.

The saline infiltration from the lagoon bottom is controlled by an over-consolidated clay layer and the presence of buried geomorphological structures, generally sandy bodies (e.g., paleo-channels).

In the mainland, sandy buried paleo-channel systems can increase the saltwater flow from the lagoon into the low-lying sectors, while sandy paleo-ridge systems are capable to contain fresh groundwater.

Saltwater intrusion is worryingly spreading in the whole southern sector, mostly in the low-lying farmland, with the exception of the zones around the Brenta river where the contamination is restricted.

Concluding, further quantitative investigations targeted at quantifying the continental and marine surface watergroundwater exchanges, as well as at developing numerical models for the prediction of the future behaviour in light of the expected climate changes, will benefit from the outcomes of this study. Moreover, this work can help detecting the zones at higher risk, where local more detailed investigations must be performed to improve the knowledge of the vulnerability of the farmland to saltwater contamination. 
Data availability. The AEM data presented here are part of an ongoing project and, therefore, will be available on completion of the research. They will be available on the website of the Institute of Marine Sciences - National Research Council, Italy (http://www.ismar.cnr.it/index_html-1?set_language=en\&cl=en). Geological and hydrogeological data are available through the following websites: Città Metropolitana Venezia (2017) http://webgis.cittametropolitana.ve.it/geologia, http://difesasuolo.provincia.venezia.it/DifesaSuolo/Index?

pagina $=1 \&$ id=banca_dati_idrogeologica; Istituto Superiore per la Protezione e la Ricerca Ambientale (2017) http://www.isprambiente.gov.it/Media/carg/veneto.html; CNRISMAR, CORILA, Regione del Veneto, Magistrato alle Acque di Venezia, ARPA Veneto, Consiglio di Bacino Laguna di Venezia, Geoportale Nazionale, IVSLA, Ist. Parco Laguna di Venezia, Ist. Bosco e Grandi Parchi, Museo di Storia Naturale di Venezia, Istituzione Centro Previsioni e Segnalazioni Maree (2017) http://cigno.atlantedellalaguna.it; Regione del Veneto (2017) http: //gisgeologia.regione.veneto.it/website/venezia-10k/viewer.htm.

Competing interests. The authors declare that they have no conflict of interest.

Special issue statement. This article is part of the special issue "Innovative water resources management - understanding and balancing interactions between humankind and nature". It is a result of the 8th International Water Resources Management Conference of ICWRS, Beijing, China, 13-15 June 2018.

Acknowledgements. The Flagship Project RITMARE - The Italian Research for the Sea - coordinated by the Italian National Research Council and funded by the Italian Ministry of Education, University and Research within the National Research Program 2011-2013.

Edited by: Depeng Zuo

Reviewed by: two anonymous referees

\section{References}

Bonardi, M., Tosi, L., Rizzetto, F., Brancolini, G., and Baradello, L.: Effects of climate changes on the late Pleistocene and Holocene sediments of the Venice Lagoon, Italy, J. Coastal. Res., 39, 279 284, 2006.

Carbognin, L. and Tosi, L.: Il Progetto ISES per l'analisi dei processi di intrusione salina e subsidenza nei territori meridionali delle Province di Padova e Venezia, Grafiche Erredici, Padova (Italy), 95 pp., 2003.

Città Metropolitana Venezia: http://webgis.cittametropolitana.ve. it/geologia, http://difesasuolo.provincia.venezia.it/DifesaSuolo/ Index?pagina=1\&id=banca_dati_idrogeologica, Banca dati geologica e idrogeologica, last access: 30 December 2017.

CNR-ISMAR, CORILA, Regione del Veneto, Magistrato alle Acque di Venezia, ARPA Veneto, Consiglio di Bacino Laguna di Venezia, Geoportale Nazionale, IVSLA, Ist. Parco Laguna di
Venezia, Ist. Bosco e Grandi Parchi, Museo di Storia Naturale di Venezia, Istituzione Centro Previsioni e Segnalazioni Maree, http://cigno.atlantedellalaguna.it, Atlante della Laguna, last access: 30 December 2017.

Da Lio, C., Tosi, L., Zambon, G., Vianello, A., Baldin, G., Lorenzetti, G., Manfe, G., and Teatini, P.: Long-term groundwater dynamics in the coastal confined aquifers of Venice (Italy), Estuar. Coast. Shelf Sci., 135, 248-259, 2013.

Da Lio, C., Carol, E., Kruse, E., Teatini, P., and Tosi, L.: Saltwater contamination in the managed low-lying farmland of the Venice coast, Italy: An assessment of vulnerability, Sci. Total Environ., 533, 356-369, 2015.

de Franco, R., Biella, G., Tosi, L., Teatini, P., Lozej, A., Chiozzotto, B., Giada, M., Rizzetto, F., Claude, C., Mayer, A., Bassan, V., and Gasparetto-Stori, G.: Monitoring the saltwater intrusion by Time Lapse Electrical Resistivity Tomography: The Chioggia test site (Venice Lagoon, Italy), J. Appl. Geophys., 69, 117-130, 2009.

Istituto Superiore per la Protezione e la Ricerca Ambientale: http://www.isprambiente.gov.it/Media/carg/veneto.html, Progetto CARG, last access: 30 December 2017.

Mayer, A., Gattacceca, J., Claude, C., Radakovitch, O., Giada, M., Cucco, A., Tosi, L., and Rizzetto, F.: Radon activity in the southern Lagoon of Venice and the Adriatic Sea, in: Scientific Research and Safeguarding of Venice 2005, edited by: Campostrini, P., CORILA, Research Program 2004-2006, 4, 217 226, Venezia, 2006.

Rapaglia, J.: Submarine groundwater discharge into the Venice lagoon, Italy, Estuaries, 28, 705-713, 2005.

Regione del Veneto: http://gisgeologia.regione.veneto.it/website/ venezia-10k/viewer.htm, Progetto CARG, last access: 30 December 2017.

Rizzetto, F., Tosi, L., Carbognin, L., Bonardi, M., and Teatini, P.: Geomorphic setting and related hydrogeological implications of the coastal plain south of the Venice Lagoon, Italy, IAHS-AISH Publ., 278, 463-470, 2003.

Teatini, P., Tosi, L., Viezzoli, A., Baradello, L., Zecchin, M., and Silvestri, S.: Understanding the hydrogeology of the Venice lagoon subsurface with airborne electromagnetics, J. Hydrol., 411, 342-354, 2011.

Tosi, L., Rizzetto, F., Bonardi, M., Donnici, S., Serandrei Barbero, R., and Toffoletto, F.: Note illustrative della Carta Geologica d'Italia alla scala 1: 50.000, Foglio 148-149 ChioggiaMalamocco, APAT, Dipartimento Difesa del Suolo, Servizio Geologico d'Italia, SystemCart, Roma, 164 pp., 2 Maps, 2007.

Tosi, L., Rizzetto, F., Zecchin, M., Brancolini, G., and Baradello, L.: Morphostratigraphic framework of the Venice lagoon (Italy) by very shallow water VHRS surveys: evidence of radical changes triggered by human-induced river diversions, Geophys. Res. Lett., 36, https://doi.org/10.1029/2008GL037136, 2009.

Tosi, L., Baradello, L., Teatini, P., Zecchin, M., Bonardi, M., Shi, P., Tang, C., Li, F., Brancolini, G., Chen, Q., Chiozzotto, B., Frankenfield, J., Giada, M., Liu, D., Nieto, D., Rizzetto, F., Sheng, Y., Xiao, Y., and Zhou, D.: Combined continuous electrical tomography and very high resolution seismic surveys to assess continental and marine groundwater mixing, Boll. Geofis. Teor. Appl., 52, 585-594, 2011.

Viezzoli, A., Tosi, L., Teatini, P., and Silvestri, S.: Surface water-groundwater exchange in transitional coastal environments by airborne electromagnetics: the Venice 
Lagoon example, Geophys. Res. Lett., 37, L01402, https://doi.org/10.1029/2009GL041572, 2010.
Zecchin, M., Caffau, M., and Tosi, L.: Relationship between peat bed formation and climate changes during the last glacial in the Venice area, Sediment. Geol., 238, 172-180, 2011. 